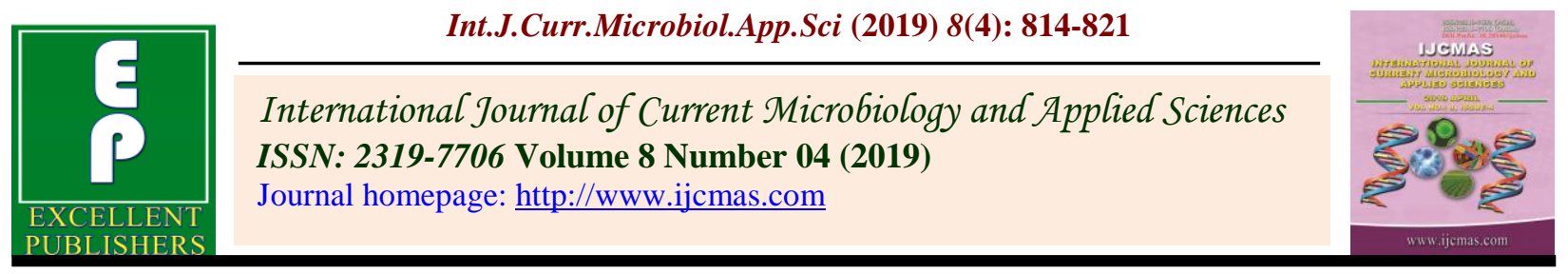

Original Research Article

https://doi.org/10.20546/ijcmas.2019.804.091

\title{
Effect of Seed Inoculation of Zinc and Iron Solubilizing Microorganisms on Soil Microbial Count as Influenced by Different Treatments at Panicle Initiation and Harvest Stage of Wheat in Inceptisol
}

\author{
Arigela Kiran $^{1 *}$ and P.P. Kadu ${ }^{2}$ \\ Department of soil science and agricultural chemistry, Mahatma Phule Krishi Vidyapeeth, \\ Rahuri-413722, Maharashtra, India \\ *Corresponding author:
}

A B S T R A C T

Keywords

Wheat, Zinc and Iron Solubilising Microorganisms, Soil microbial count, Zinc solubilising bacteria and fungi, Iron and zinc solubilising bacteria and fungi

Article Info

Accepted: 07 March 2019 Available Online: 10 April 2019
A field experiment was conducted during the year 2015-16 at Post Graduate Institute Farm, Mahatma Phule Krishi Vidyapeeth, Rahuri, to study the "Effect of Seed Inoculation of Zinc and Iron Solubilizing Microorganisms on Yield and Nutrient Uptake of Wheat in Inceptisol. The highest microbial population was also observed in treatment $\mathrm{T}_{7}$, which was at par with treatment $T_{6}$ and $T_{5}$, in panicle initiation and harvest stage, with a slight decline at the harvest stage of wheat. The result presented in table 4 and 5 indicated a significant increase in soil bacterial and fungal count at panicle initiation stage of wheat. This increase in the microbial population was observed in treatment $\mathrm{T}_{7}$. The highest bacterial and fungal population was in the treatment $T_{7}$, which was observed to be at par with treatments $T_{5}$ and $\mathrm{T}_{6}$. The same trend in microbial population was observed at harvest stage with slight decrease in the population over the panicle initiation stage.

\section{Introduction}

Wheat (Triticum aestivum) is the second most important cereal crop in India next to rice in respect of area and production. In 2016, global wheat production was 749 million tonnes. Wheat is the primary food staple in North Africa and the Middle East, and is growing in uses in Asia. Unlike rice, wheat production is more widespread globally, though $47 \%$ of the world total in 2014 was produced by just four countries - China, India, Russia and the United States. In India, area under wheat cropping in 2015-16 was 29.25 million hectares with the annual production of 85.93 million tonnes with average productivity of $2938 \mathrm{~kg} \mathrm{ha}{ }^{-1}$. In Maharashtra, wheat occupied 1.08 million hectare and annual production was 1.74 million tonnes with average productivity of 
$1483 \mathrm{kgha}^{-1}$ (Anonymous, 2015). The average productivity of wheat in Maharashtra is quite low. Therefore, it is very essential to increase the production and productivity of wheat in the state. The deficiencies of micronutrients ( $\mathrm{Zn}$ and $\mathrm{Fe}$ ) have been increasing on many agricultural soils. It can be grown in tropics, sub tropics and temperate region. Wheat is cultivated in alluvial soil and black cotton soils. Wheat is an important source of carbohydrate, proteins and minerals like $\mathrm{P}, \mathrm{Mg}, \mathrm{Fe}, \mathrm{Cu}$ and $\mathrm{Zn}$ and vitamins like thiamine, riboflavin, niacin and Vitamin E. The micronutrient deficiencies have been verified in many soils through soil testing and plant analysis. The application of micronutrient fertilizers have proved better in many agricultural crops viz., wheat, maize, rice etc.

Zinc is one of the most important micronutrients. It has vital role in transformation of carbohydrates, regulation of consumption of sugar and increase source of energy for the production of chlorophyll. Zinc is also required for maintenance of auxin in an active state. Zinc is essential for the synthesis of tryptophan, a precursor of auxin. The basic function of zinc in plants relates to metabolism of carbohydrate, protein and phosphate, auxin and ribosome formation. The intensive cropping, imbalanced fertilization, non-use of micronutrients and inadequate supply of organic manures have resulted in the depletion of soil fertility. Iron is involved in the production of chlorophyll and iron chlorosis is easily recognized on iron sensitive crops growing on calcareous soil. Iron also is a component of many enzymes associated with energy transfer, nitrogen reduction and fixation and lignin formation. Iron is associated with sulphur in plants to form compounds that catalyse other reactions. Iron deficiencies are mainly manifested by yellow leaves due to low levels of chlorophyll. Leaf yellowing first appears on the younger upper leaves in interveinal tissues. Severe iron deficiencies cause leaves to turn completely yellow or almost white and then brown as leaves die. Iron deficiencies are found mainly on high $\mathrm{pH}$ soil, although some acid, sandy soil low in organic matter also may be iron deficient. Cool, wet weather enhances iron deficiencies, especially on soil with marginal level of available iron. Poorly aerated or compacted soil also reduce iron uptake by plants, uptake of iron decreases with increase in soil $\mathrm{pH}$ and is adversely affected by high level of available phosphorus, manganese and zinc in soil. Wheat is the crop species which is most susceptible to zinc deficiency. About 96 to 99 percent of the applied zinc and iron is concerted to different insoluble forms depending upon the soil types, physicochemical reactions of the soil. The solubility of zinc and iron is highly dependent on soil $\mathrm{pH}$ and moisture. Zinc occurs in soil as sphalerite, olivine, hornblende, augite and biotite. Adoption of recommended package of practices is a need of the day. Macro and micronutrients play a vital role in the physiology of plants. The application of micronutrient either foliar or through soil is very essential for higher production and quality improvement of wheat. Amongst the micronutrients, iron and zinc have recently assumed greater importance in crop production. The information on seed coating of iron and zinc solubilizing microorganisms to solubilize the soil mineral zinc and iron is very scanty and staggered.

\section{Materials and Methods}

The experiment was laid out in a Randomized Block Design with 7 treatments and 3 replications. The gross plot size was $3.60 \mathrm{x}$ $4.50 \mathrm{~m}$ and net plot size was $3.15 \times 4.10 \mathrm{~m}$. The recommended spacing of $22.5 \mathrm{~cm}$ was adopted. The experimental plot belonging to Inceptisol order, deficient in $\mathrm{Zn}$ and $\mathrm{Fe}$ and 
low status of organic carbon content was selected for conduct of experiment. Composite soil sample from the experimental site was collected and processed for analysis of soil properties and fertility. After collection soil, the soil was air dried under diffused sunlight and processed for initial chemical properties. Well decomposed farmyard manure was procured from cattle project, M.P.K.V., Rahuri and applied as per recommendation @ $10 \mathrm{t} \mathrm{ha}^{-}$. The Fe- $\mathrm{Zn}$ solubilizing culture required for seed coating for this experiment, was brought from the Vasantdada Sugar Institute, Manjari, Dist. Pune. The culture consisted of a consortium of zinc and iron solubilizing bacteria and fungi. The zinc solubilizers included a consortium of bacterial strains viz., Bacilus polymyxa, Bacillus megaterium, Psuedomonas striata, Psuedomonas fluroscense, Glucanoacetabactor diazotrophicus and Aspergillus awamoriea fungal strain. The iron solubilizing microorganisms included bacterial strains viz. Thiobacillus thioxidans, Thiobacillus ferroxidans and Aspergillus niger and Trichoderma viridae, which are the fungal strains. This consortium of iron and zinc solubilizing organisms were used for wheat seed inoculation.

\section{Experimental site}

The experimental plot belonging to Inceptisol order, deficient in $\mathrm{Zn}$ and $\mathrm{Fe}$ and low status of organic carbon content was selected for conduct of experiment.

\section{Soil}

Composite soil sample from the experimental site was collected and processed for analysis of soil properties and fertility. After collection soil, the soil was air dried under diffused sunlight and processed for initial chemical properties.

\section{FYM}

Well decomposed farmyard manure was procured from cattle project, M.P.K.V., Rahuriand applied as per recommendation@ $10 \mathrm{t} \mathrm{ha}^{-1}$.

\section{Culture media}

PDA and nutrient agar media were used for the isolation of zinc and iron solubilizing bacteria and zinc and iron solubilizing fungus, respectively for initial microbial population count, at panicle initiation stage and at harvest stage of crop.

\section{Treatments details}

$\mathrm{T}_{1}:$ Absolute control

$\mathrm{T}_{2}$ : Absolute control + seed treatment of $\mathrm{Zn}$ and Fe solubilizers

$\mathrm{T}_{3}$ : GRDF only (120:60:40 $\mathrm{kg} \mathrm{ha}^{-1} \mathrm{~N}$, $\mathrm{P}_{2} \mathrm{O}_{5}$ and $\left.\mathrm{K}_{2} \mathrm{O}+10 \mathrm{t} \mathrm{ha}^{-1} \mathrm{FYM}\right)$

$\mathrm{T}_{4}$ : GRDF + seed treatment of $\mathrm{Zn}$ and $\mathrm{Fe}$ solubilizers

$\mathrm{T}_{5}: \mathrm{GRDF}+5 \mathrm{~kg} \mathrm{ha}^{-1} \mathrm{ZnSO}_{4}+10 \mathrm{~kg} \mathrm{ha}^{-1}$ $\mathrm{FeSO}_{4}+\mathrm{Zn}$ and $\mathrm{Fe}$ solubilizers

$\mathrm{T}_{6}: \mathrm{GRDF}+10 \mathrm{~kg} \mathrm{ha}^{-1} \mathrm{ZnSO}_{4}+15 \mathrm{~kg} \mathrm{ha}^{-1}$ $\mathrm{FeSO}_{4}+\mathrm{Zn}$ and Fe solubilizers

$\mathrm{T}_{7}: \mathrm{GRDF}+20 \mathrm{~kg} \mathrm{ha}^{-1} \mathrm{ZnSO}_{4}+25 \mathrm{~kg}$ $\mathrm{ha}^{-1} \mathrm{FeSO}_{4}+\mathrm{Zn}$ and $\mathrm{Fe}$ solubilizers

Note: Half of $\mathrm{N}$, total $\mathrm{P}_{2} \mathrm{O}_{5}$ and $\mathrm{K}_{2} \mathrm{O}$ was applied the time of sowing; remaining half of $\mathrm{N}$ was given at $30 \mathrm{DAS}$.

Total microbial count by serial dilution and standard plate count method

At initial, panicle initiation and harvesting stage soil samples were collected for total microbial count. The population of bacteria and fungi was enumerated by the serial dilution and standard plate count method using nutrient agar media for zinc and iron solubilizing bacteria and potato dextrose agar 
media for zinc and iron solubilizing fungi.

Isolation was carried out by using the following procedures:

One gram $(1 \mathrm{~g})$ of soil sample was dispersed in $9 \mathrm{ml}$ of autoclaved distilled water and thoroughly shaken.

One millilitre $(1 \mathrm{ml})$ of the above solution was transferred to $9 \mathrm{ml}$ of sterile distilled water to form $10^{2}$ dilution.

Similarly, $10^{3}, 10^{4}, 10^{5}, 10^{6}, 10^{7}$ and $10^{8}$ serials were made for each soil sample.

One millilitre $(1 \mathrm{ml})$ of each dilution was transferred to sterile petri plates separately.

Solidifiable Pikovskaya's agar medium having $\left(45^{\circ} \mathrm{C}\right.$ temp) was poured in the petri plates.

The contents were mixed by rotating the plates gently. Care was taken that medium did not touch the lid.

The medium was allowed to solidify and the plates were incubated at $27-30^{\circ} \mathrm{C}$ for 7 days.

The same procedure was followed for the isolation of zinc and iron solubilising fungi using potato dextrose agar medium.

The development of whitish colonies of zinc and iron solubilizing bacteria were observed within 24-48 hrs in the nutrient agar medium plate and whitish, blackish and greenish cottony colonies of zinc and iron solubilizing fungi were observed after 4 days of incubation in the potato dextrose agar medium plate.

The average number of bacterial and fungal colonies per plate was counted separately and population count was computed.

\section{Results and Discussion}

\section{Soil microbial count as influenced by different treatments at panicle initiation stage of wheat}

\section{Soil bacterial count}

The soil bacterial count (Table 4) was observed to increase significantly from $\mathrm{T}_{2}$ to $\mathrm{T}_{7}$ over absolute control. The increase in bacterial population was also significantly higher in treatment $\mathrm{T}_{7}$, over other treatments.

The highest bacterial count was observed in treatment $\mathrm{T}_{7}\left(21.41\right.$ cfux $10^{6} \mathrm{~g}^{-1}$ soil $)$. These increase was at par with treatment by $\mathrm{T}_{6}$ (19.34 cfux $10^{6} \mathrm{~g}^{-1}$ soil) and $\mathrm{T}_{5}\left(20.60 \mathrm{cfux} 10^{6}\right.$ $\mathrm{g}^{-1}$ soil), The bacterial count in seed inoculation treatments were much higher than treatment $\mathrm{T}_{3}\left(5.13 \mathrm{cfux} 10^{6} \mathrm{~g}^{-1}\right.$ soil $)$ i.e. recommended dose of fertilizer. The lowest bacterial count was observed in treatment $T_{1}$ (2.67 cfux $10^{6} \mathrm{~g}^{-1}$ soil). The results invariably indicate usefulness of seed coating of $\mathrm{Fe}$ and $\mathrm{Zn}$ solubilizers to increase the soil bacteria. This may be due to increasing the soil bacterial population through seed inoculation of zinc and iron solubilizers. Similar observations were recorded by Poonam et al., (2014) (Fig. 1).

\section{Soil fungal count}

The soil fungal count at panicle initiation stage of wheat. This increase in the microbial population was observed in treatment $\mathrm{T}_{7}$. The soil fungal count (Table.1) of soil was observed to increase significantly from $T_{2}$ to $\mathrm{T}_{7}$, over absolute control. The increase in fungal population was also significantly higher in treatment $T_{7}$, over other treatments.

The highest fungal count was observed in treatment $\mathrm{T}_{7} \quad\left(19.55 \mathrm{cfux} 10^{5} \mathrm{~g}^{-1}\right.$ soil), this increase was at par with $\mathrm{T}_{6}\left(19.27 \mathrm{cfu} \times 10^{5} \mathrm{~g}^{-}\right.$ 
${ }^{1}$ soil) and $\mathrm{T}_{5}\left(18.84 \mathrm{cfu} \times 10^{5} \mathrm{~g}^{-1}\right.$ soil). The lowest microbial fungal count was observed in the treatment $\mathrm{T}_{1}\left(2.82 \mathrm{cfu} \times 10^{5} \mathrm{~g}^{-1}\right.$ soil $)$. The fungal count in seed inoculation treatments were much higher than treatment $\mathrm{T}_{3}(4.22$ cfux $10^{5} \mathrm{~g}^{-1}$ soil)i.e recommended dose of fertilizer. The result indicated usefulness of seed coating of $\mathrm{Fe}$ and $\mathrm{Zn}$ solubilizers to increase the soil fungal population. Ghodpage et al., (2009) also reported as increase in soil fungi population by use of $75 \% \mathrm{RDF}+$ amrutpani and seed inoculation of bio fertilizers to cotton (Fig. 2).

Table.1 Effect of seed inoculation of $\mathrm{Zn}$ and Fe solubilizers on soil microbial count at panicle initiation stage of wheat

\begin{tabular}{|c|c|c|c|}
\hline $\begin{array}{l}\text { Tr. } \\
\text { No. }\end{array}$ & Treatment & $\begin{array}{c}\text { Bacteria } \\
\text { (cfux } 10^{6} \mathrm{~g}^{-1} \text { soil) }\end{array}$ & $\begin{array}{c}\text { Fungi } \\
\left(\text { cfu } \times 10^{5} \mathrm{~g}^{-1} \text { soil }\right)\end{array}$ \\
\hline $\mathbf{T}_{1}$ & Absolute control & 2.67 & 2.82 \\
\hline $\mathbf{T}_{2}$ & Absolute control + seed treatment of $\mathrm{Zn}$ and Fe solubilizers & 6.18 & 4.07 \\
\hline $\mathbf{T}_{3}$ & GRDF only $\left(120: 60: 40 \mathrm{~kg} \mathrm{ha}^{-1} \mathrm{~N}, \mathrm{P}_{2} \mathrm{O}_{5} \& \mathrm{~K}_{2} \mathrm{O}+10 \mathrm{t} \mathrm{ha}^{-1} \mathrm{FYM}\right)$ & 5.13 & 4.22 \\
\hline $\mathbf{T}_{4}$ & GRDF + seed treatment of $\mathrm{Zn}$ and Fe solubilizers & 6.63 & 5.54 \\
\hline $\mathbf{T}_{5}$ & $\begin{array}{l}\mathrm{GRDF}+5 \mathrm{~kg} \mathrm{ha}^{-1} \mathrm{ZnSO}_{4}+10 \mathrm{~kg} \mathrm{ha}^{-1} \mathrm{FeSO}_{4}+\mathrm{Zn} \text { and Fe } \\
\text { solubilizers }\end{array}$ & 20.60 & 18.84 \\
\hline $\mathbf{T}_{6}$ & $\begin{array}{l}\mathrm{GRDF}+10 \mathrm{~kg} \mathrm{ha}^{-1} \mathrm{ZnSO}_{4}+15 \mathrm{~kg} \mathrm{ha}^{-1} \mathrm{FeSO}_{4}+\mathrm{Zn} \text { and Fe } \\
\text { solubilizers }\end{array}$ & 19.34 & 19.27 \\
\hline $\mathbf{T}_{7}$ & $\begin{array}{l}\mathrm{GRDF}+20 \mathrm{~kg} \mathrm{ha}^{-1} \mathrm{ZnSO}_{4}+25 \mathrm{~kg} \mathrm{ha}^{-1} \mathrm{FeSO}_{4}+\mathrm{Zn} \text { and Fe } \\
\text { solubilizers }\end{array}$ & 21.41 & 19.55 \\
\hline & Initial & 3.08 & 2.05 \\
\hline & SE \pm & 1.10 & 0.89 \\
\hline & CD at $5 \%$ & 3.40 & 2.75 \\
\hline
\end{tabular}


Table.2 Effect of seed inoculation of $\mathrm{Zn}$ and Fe solubilizers on soil microbial count at harvest stage of wheat

\begin{tabular}{|c|c|c|c|}
\hline $\begin{array}{l}\text { Tr. } \\
\text { No. }\end{array}$ & Treatment & $\begin{array}{c}\text { Bacteria } \\
\left.\text { (cfu } \times 10 \mathrm{~g}^{-1} \text { soil }\right)\end{array}$ & $\begin{array}{c}\text { Fungi } \\
\left(\text { cfu } \times 10^{5} \mathrm{~g}^{-1} \text { soil }\right)\end{array}$ \\
\hline $\mathbf{T}_{1}$ & Absolute control & 2.21 & 1.24 \\
\hline $\mathbf{T}_{2}$ & $\begin{array}{l}\text { Absolute control + seed treatment of } \\
\mathrm{Zn} \text { and Fe solubilizers }\end{array}$ & 5.38 & 3.05 \\
\hline $\mathbf{T}_{3}$ & $\begin{array}{l}\text { GRDF only }\left(120: 60: 40 \mathrm{~kg} \mathrm{ha}^{-1} \mathrm{~N}\right. \\
\left.\mathrm{P}_{2} \mathrm{O}_{5} \& \mathrm{~K}_{2} \mathrm{O}+10 \mathrm{t} \mathrm{ha}^{-1} \mathrm{FYM}\right)\end{array}$ & 3.88 & 2.18 \\
\hline $\mathbf{T}_{4}$ & $\begin{array}{l}\text { GRDF + seed treatment of } \mathrm{Zn} \text { and Fe } \\
\text { solubilizers }\end{array}$ & 5.40 & 4.87 \\
\hline $\mathbf{T}_{5}$ & $\begin{array}{l}\mathrm{GRDF}+5 \mathrm{~kg} \mathrm{ha}^{-1} \mathrm{ZnSO}_{4}+10 \mathrm{~kg} \mathrm{ha}^{-1} \\
\mathrm{FeSO}_{4}+\mathrm{Zn} \text { and Fe solubilizers }\end{array}$ & 15.79 & 8.98 \\
\hline $\mathbf{T}_{6}$ & $\begin{array}{l}\mathrm{GRDF}+10 \mathrm{~kg} \mathrm{ha}^{-1} \mathrm{ZnSO}_{4}+15 \mathrm{~kg} \mathrm{ha}^{-} \\
{ }^{1} \mathrm{FeSO}_{4}+\mathrm{Zn} \text { and Fe solubilizers }\end{array}$ & 18.38 & 11.98 \\
\hline $\mathbf{T}_{7}$ & $\begin{array}{l}\mathrm{GRDF}+20 \mathrm{~kg} \mathrm{ha}^{-1} \mathrm{ZnSO}_{4}+25 \mathrm{~kg} \mathrm{ha}^{-} \\
{ }^{1} \mathrm{FeSO}_{4}+\mathrm{Zn} \text { and Fe solubilizers }\end{array}$ & 19.36 & 12.11 \\
\hline \multicolumn{2}{|r|}{ Initial } & 3.08 & 2.05 \\
\hline \multicolumn{2}{|r|}{$\mathrm{SE} \pm$} & 0.745 & 0.848 \\
\hline \multicolumn{2}{|r|}{ CD at $5 \%$} & 2.29 & 2.61 \\
\hline
\end{tabular}

Fig.1 Effect of seed inoculation of Zn and Fe solubilizers on soil bacterial count at panicle initiation and harvest stage of wheat

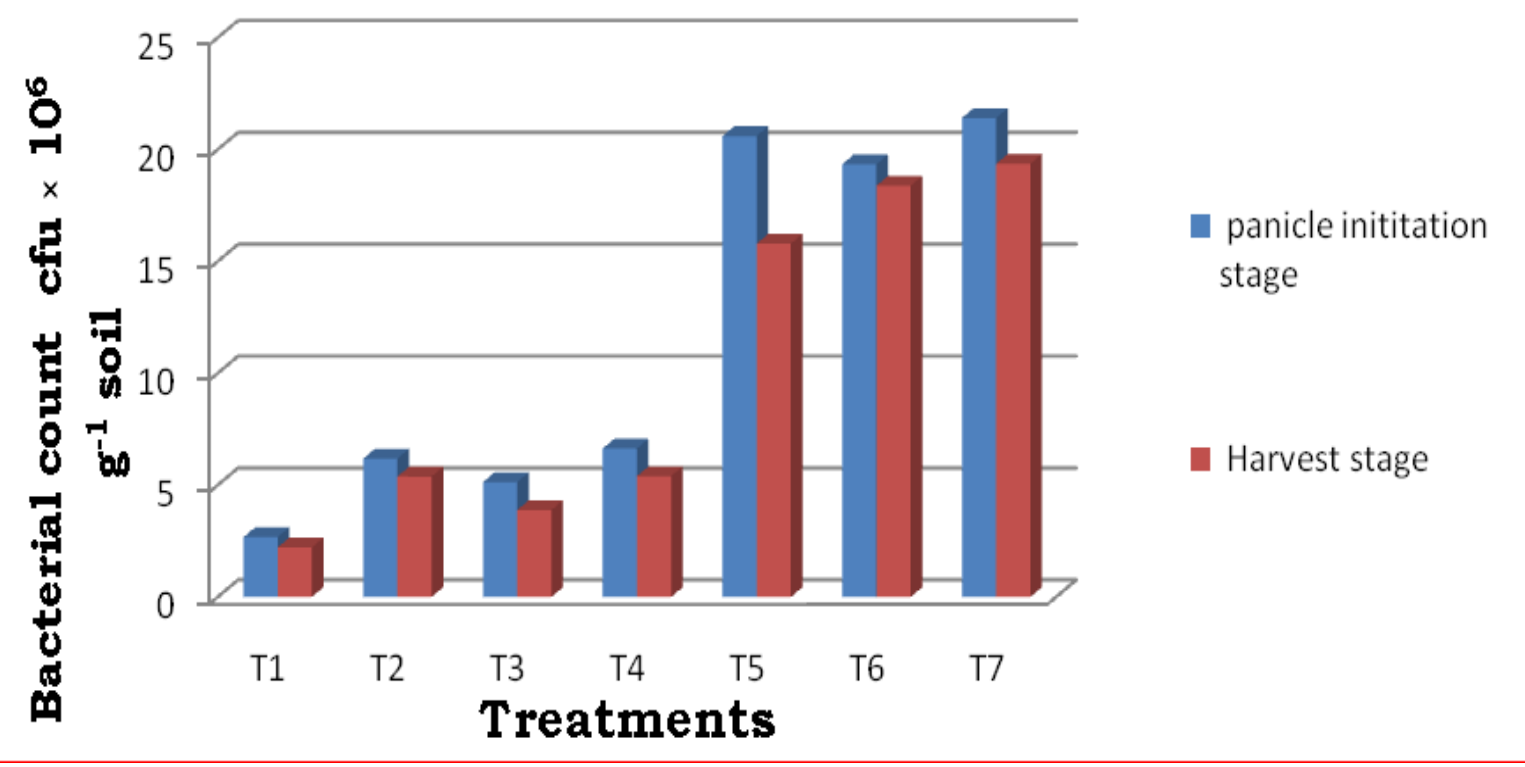


Fig.2 Effect of seed inoculation of $\mathrm{Zn}$ and Fe solubilizers on soil fungal count at panicle initiation and harvest stage of wheat

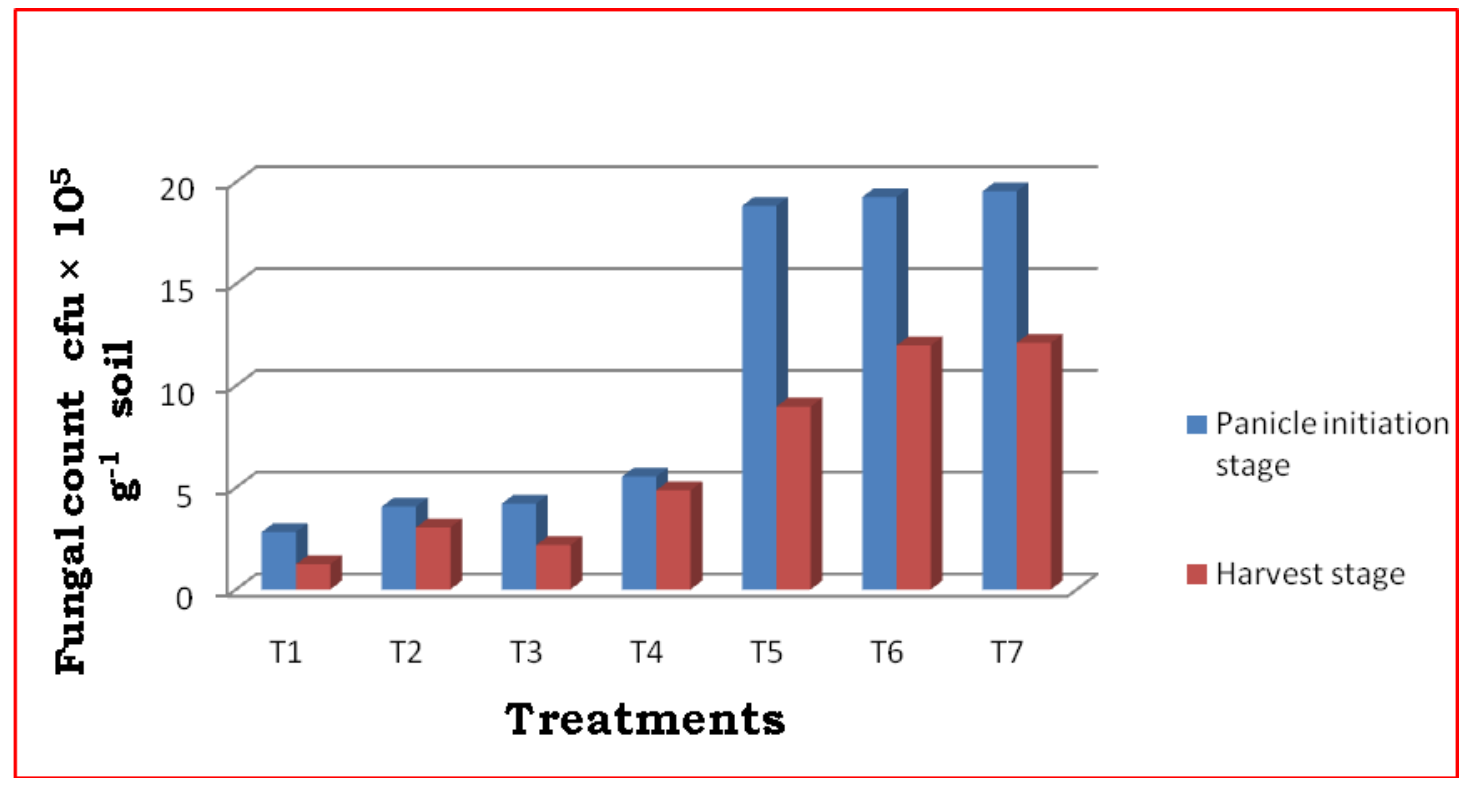

Effect of seed inoculation of $\mathrm{Zn}$ and $\mathrm{Fe}$ solubilizers on soil microbial count at harvest stage of wheat

The same trend in microbial population was observed at harvest stage with slight decrease in the population over the harvest stage.

\section{Soil bacterial count}

The soil bacterial count (Table 2) of wheat was observed to increase significantly from $\mathrm{T}_{2}$ to $\mathrm{T}_{7}$ over absolute control. The increase in bacterial population was also significantly higher in treatment $\mathrm{T}_{7}$, over other treatments.

The highest bacterial count was observed in treatment $\mathrm{T}_{7}\left(19.36\right.$ cfux $10^{6} \mathrm{~g}^{-1}$ soil), this increase was at par with $\mathrm{T}_{6}\left(18.38 \mathrm{cfux} 10^{6} \mathrm{~g}^{-1}\right.$ soil). The bacterial count in seed inoculation treatments were much higher than treatment $\mathrm{T}_{3} \quad\left(3.88 \mathrm{cfux} 10^{6} \mathrm{~g}^{-1}\right.$ soil) i.e. recommended dose of fertilizer. The lowest bacterial count was observed in treatment $\mathrm{T}_{1}\left(2.21 \mathrm{cfux} 10^{6} \mathrm{~g}^{-1}\right.$ soil). The result invariably indicate usefulness of seed coating of Fe and $\mathrm{Zn}$ solubilizers.

\section{Soil fungal count}

The soil fungal count at harvest stage of wheat is given in Table 5. The increase in the microbial population was observed in treatment $\mathrm{T}_{7}$. The highest fungi in treatment $\mathrm{T}_{7}\left(12.11 \mathrm{cfu} \times 10^{5} \mathrm{~g}^{-1}\right.$ soil $)$, this increase at par with $\mathrm{T}_{6}\left(11.98 \mathrm{cfu} \times 10^{5} \mathrm{~g}^{-1}\right.$ soil $)$. The lowest microbial fungal count was observed in the treatment $\mathrm{T}_{1}\left(1.24 \mathrm{cfu} \times 10^{5} \mathrm{~g}^{-1}\right.$ soil $)$.

The fungal countin seed inoculation treatments were much higher than treatment $\mathrm{T}_{3} \quad\left(2.18 \mathrm{cfux} 10^{5} \mathrm{~g}^{-1}\right.$ soil) i.e. recommended dose of fertilizer. The results in variably indicate usefulness of seed coating of $\mathrm{Fe}$ and $\mathrm{Zn}$ solubilizers. Similar findings were reported by Ghodpage et al., (2009)

The result may be attributed to high organic carbon content of zinc and iron solubilizers which helped to increase the bacterial and fungal population. Organic carbon served as source of food and energy for soil microorganisms. 
Effect of seed inoculation of $\mathrm{Zn}$ and $\mathrm{Fe}$ solubilizers on soil microbial population

The result presented in table 4 indicated a significant increase in soil bacterial and fungal count at panicle initiation stage of wheat. This increase in the microbial population was observed in treatment $\mathrm{T}_{7}$. The highest bacterial and fungal population was in the treatment $\mathrm{T}_{7}$, which was observed to be at par with treatments $\mathrm{T}_{5}$ and $\mathrm{T}_{6}$.

The same trend in microbial population was observed at harvest stage with slight decrease in the population over the panicle initiation stage.

\section{References}

Anonymous, (2015) www.india.stat.com.

Chonnkar, P.K., Bhaduraraj, S., Patra, A.K. and Purukayastha, T.J. (2007) Enumeration of soil biota. In: Experiment in Soil Biology and Biochemistry. Westrille publishing house, New Delhi, pp. 1-80.

Ghodpage, R.M., Balapande, S.S., Harale, M.A. and Mandale, M.G. (2009) Effect of amrutpani and biofertilizer with fertilizer and vermicompost on soil microbiota and yield of rainfed cotton. Journal of Soils and Crops, 19, 343346.

Haselwandter, K. (2008) Structure and function of siderophores produced by mycorrhizal fungi. Mineral Magine, 72, 61-64.

Hildebrandt, U., Ouziad, F., Marner, F.J. and
Bothe, H. (2006) The bacterium Paenibacillus validus stimulates growth of the arbuscular mycorrhizal fungus Glomus intraradices up to the formation of fertile spores. International Research Journal of Microbiology 254, 258-267.

Janaki, D. and Velu, V.(2010) Effect of different bacterial strains on zinc solubilization in maize. Indian Journal of Microbiology 5, 244-248.

Marschner, P. and Crowley, D.E. (1998) Phytosiderophore decrease iron stress and pyo-verdine production of Pseudomonas fluorescensPf-5.Journal Soil Biochemistry 30, 1275-1280.

Nahas and Sayer (1996)Factors determining rock phosphate solubilization by microorganisms isolated from soil, World Journal of Microbiology and Biotechnology, 12, 567-572.

Poonam, S., Kumawat, K.C., Sabhjeet, C. and Navprabhjot K. (2014). Assesment of zinc solubilization by endophytic bacteria in legume Rhizosphere. Indian Journal of Applied Research, 22, 12-14.

Sayer, J.A. and Gadd, G.M. (1997) Solubilization and transformation of insoluble inorganic metal compounds to insoluble metal oxalates by Aspergillus niger. Mycological Research 6, 653661.

Sharma, A., Johri, B.N., Sharma, A.K. and Glick, B.R. (2003) Plantgrowthpromoting bacterium Pseudomonas sp. strain GRP3 influences iron acquisition in mung bean (Vigna radiata L.). Soil Biochemistry 35, 887-894.

\section{How to cite this article:}

Arigela Kiran and Kadu, P.P. 2019. Effect of Seed Inoculation of Zinc and Iron Solubilizing Microorganisms on Soil Microbial Count as Influenced by Different Treatments at Panicle Initiation and Harvest Stage of Wheat in Inceptisol. Int.J.Curr.Microbiol.App.Sci. 8(04): 814821. doi: https://doi.org/10.20546/ijcmas.2019.804.091 